\title{
The Association between Audit Committee Members' Multiple Directorship, Ownership and Earnings Management in Saudi Arabia
}

\author{
Mohammed Alshetwi \\ Correspondence: Mohammed Alshetwi, College of Business \& Economics, Department of Accounting, Qassim \\ University, Saudi Arabia. E-mail: mohd778@ hotmail.com
}

Received: August 4, 2016

Accepted: August 18, 2016

Online Published: August 25, 2016

doi:10.5539/ibr.v9n10p33

URL: http://dx.doi.org/10.5539/ibr.v9n10p33

\begin{abstract}
This study examines the association between the multiple directorship and stock ownership of audit committee members and companies' earnings management. Based on a sample of 98 Saudi nonfinancial listed companies, this study finds that the multiple directorship of audit committee members is not statistically associated with a reduction in the level of earnings management; however, the stock ownership of audit committee members is significantly related to a reduction in the level of earnings management.

The results of this study add to the field of knowledge as they provide evidence on the alignment hypotheses from less developed countries (i.e. Saudi Arabia). Furthermore, these findings are useful to understand the current situation of the multiple directorship and stock ownership of audit committee members and their role in improving the monitoring system and reducing earnings management in countries with special characteristics like Saudi Arabia (i.e., with a less developed legal system and new corporate governance regulations).
\end{abstract}

Keywords: corporate governance, multiple directorship, stock ownership, audit committee, earnings management

\section{Introduction}

In recent discussions of business structure, it has been posited that a separation of ownership and management could lead to a conflict of interest between managers and stakeholders. According to Fama and Jensen (1983), managers may behave opportunistically to maximize their own interest in a manner that might not be aligned with stakeholders' objectives. One example of the conflict of interest between management and stakeholders is earnings management, when managers use their judgments to manipulate earnings at the expense of shareholders.

The audit committee (AC) is an important factor in corporate governance (CG) that plays a vital role in monitoring the opportunistic behavior of management and thereby improving alignment with shareholders' interest.

Indeed, the monitoring role of the $\mathrm{AC}$ has received significant attention in the literature in recent years (for example: Abbott, Parker, \& Peters, 2004; Bédard, Chtourou \& Courteau, 2004; Farber, 2005; Klein, 2002; Krishnan, Wen, \& Zhao, 2011; Lin, Li, \& Yang, 2006); however, more recently, researchers and commentators have turned to exploring the effect of AC members' multiple directorships and stock ownership on companies' earnings management.

With regard to multiple directorship, prior studies have sought to examine the link between multiple directorship and firm performance (Ferris, Jagannathan, \& Pritchard, 2003; Fich \& Shivdasani, 2006) financial reporting quality (FRQ) (Sharma \& Iselin, 2012) and firm value (Ahn, Jiraporn, \& Kim, 2010; Beasley, 1996; Perry \& Peyer, 2005). Two theoretical hypotheses have been advanced to explain the association between multiple directorship and earnings management. The reputation hypothesis contends that the number of directorships held by a director increases in accordance with the degree of director quality. In other words, directors who hold multiple directorships will be more sensitive about their reputation and present themselves as good monitors to obtain more directorial positions in other companies. This situation will result in an improvement in the monitoring system and a reduction in the level of earnings management. Studies that have investigated this hypothesis include Jiraporn, Singh, and Lee (2009) and Perry and Peyer (2005).

The second hypothesis is the busyness hypothesis. This hypothesis proposes that when directors hold more 
outside board seats, they become so busy that they cannot fulfill their monitoring responsibilities effectively (Ahn et al., 2010; Ferris et al., 2003; Fich \& Shivdasani, 2006), which leads to a reduction in their ability to detect and prevent earnings management.

Another issue of this study concerns the association between AC members' stock ownership held and the level of earnings management. Most studies that have investigated this issue are based on the alignment hypothesis (Alves, 2012; Teshima \& Shuto, 2008; Warfield, Wild \& Wild, 1995). The advocates of this view argue that as directors' ownership of stock in their companies increases, they will more be aligned with the interests of shareholders and thus pay greater attention to monitoring the company's performance. This, in turn, will lead to an improvement in the quality of earnings and a reduction in the level of earnings management. (Note 1)

Unlike studies that have investigated the association between multiple directorship and stock ownership with earnings management at the level of the whole board (Ahn et al., 2010; Ferris et al., 2003; Fich \& Shivdasani, 2006; Perry \& Peyer, 2005), the current study aims to investigate the issue at the level of the company's AC.

Based on sample of 98 Saudi nonfinancial listed companies, this study finds that the multiple directorship of an $\mathrm{AC}$ member is not statistically associated with a reduction in the level of earnings management. One explanation for this finding is that there is a shortage of directors with multiple directorships who serve on ACs in Saudi companies. In fact, $41 \%$ of AC members have either single or double directorship, indicating that a gap exists between the current situation and the potential number of directors with multiple directorships who could add value to the AC's performance. On other hand, this finding may indicate that less value is placed on directors with multiple directorships by the company's board of directors, which might affect their role in monitoring financial reporting. Furthermore, it implies that Saudi companies are unable to adhere to the formal governance regulation issued by the Capital Market Authority (CMA), which encourages directors to be members of other boards, providing that they do not hold more than five directorships in joint stock companies simultaneously (Capital Market Authority [CMA], 2006).

However, the current study finds that the stock ownership of AC members is significantly associated with a reduction in the level of earnings management. This result is consistent with the alignment hypothesis, suggesting that when AC members hold more common stock in their companies, they will be more motivated to improve the quality of earnings, thereby leading to a lower level of earnings management.

In a supplementary analysis, this study finds that the stock ownership of AC members has a significant impact on the level of earnings management when the level of the stock ownership of AC members is high; however, it does not have an impact when the stock ownership of AC members is at an intermediate or low level.

The findings of this study can assist policy makers in Saudi Arabia who are concerned about the current situation of AC members' multiple directorships and stock ownership. It also places emphasis on the influence of AC members' multiple directorships and stock ownership on improving a company's monitoring system and reducing earnings management. Moreover, it adds to the knowledge of the field because while most studies on these issues have been carried out in the context of advanced economies, this study provides evidence from a less developed country (i.e., Saudi Arabia).

From a practical perspective, the current study provides evidence that can help companies strategize to benefit more from directors who serve on multiple boards. In addition, the findings of this study are important to initiate long-term plans designed to motivate directors to achieve the objectives of shareholders (for example, by offering stock options and other stock-related compensation plans).

The remainder of this paper is organized as follows: Section two presents the literature review and explains the hypothesis development. Next, section three describes the research methods used, and section four presents and discusses the results of the study. Finally, section five draws conclusions and offers suggestions for future research.

\section{Literature Review and Hypothesis Development}

A separation of ownership and management calls for improving the CG system to monitor the opportunistic behavior of management. One adverse outcome of divergences of interest between management and shareholders is earnings management. This occurs when managers intentionally mislead investors by altering financial information to maximize their own interest (Schipper, 1989). (Note 2)

To reduce the level of earnings management, companies must improve their CG system. An AC is an important element of CG that helps improve the quality of earnings and reduces the likelihood of earnings management (Abbott, Park, \& Parker, 2000; Abbott et al., 2004; Farber, 2005). In particular, studies have examined the impact of specific characteristics of AC effectiveness on earnings management, including AC independence, 
competency, and diligence (Bédard et al., 2004; Klein, 2002; Krishnan et al., 2011).

For instance, a study undertaken by Klein (2002) examined the relationship between the AC, board characteristics and earnings management and found that $\mathrm{AC}$ independence was negatively related to the reduction in earnings management, as proxied by abnormal accrual. This result supported the hypothesis that an $\mathrm{AC}$ with more independent directors is more effective in monitoring the corporate financial accounting process.

Likewise, Bédard et al. (2004) investigated the effects of AC independence, expertise, and activities on aggressive earnings management. Their results revealed that aggressive earnings management was negatively associated with the presence of a majority of independent directors, with the presence of financial experts, and with the presence of a clear mandate defining the oversight responsibilities of the AC.

Another study was conducted by Velte and Stiglbauer (2011), who examined whether the establishment of an AC that had independent members with financial expertise could reduce the likelihood of earnings management. Their evidence showed a significant negative relationship between the independence and financial expertise of $\mathrm{AC}$ members and earnings management.

While most literature has focused on the associations between specific characteristics of the AC (i.e., independence, competency, and diligence), less attention has been paid to other important characteristics of AC members, such as holding multiple directorships and holding common stock ownership.

\subsection{AC Multiple Directorship and Earnings Management}

Literature on the association between multiple directorship and earnings management has been based on two competing hypotheses. Under the reputation hypothesis, it is proposed that directors gain a diversified set of information when they hold multiple board seats (Booth \& Deli, 1996).

To be eligible for a second term on a board, directors with multiple directorships should offer better monitoring work and send the signal that they are good monitors. This would imply that they were more knowledgeable about the incentive to manage earnings and more effective in fulfilling their monitoring role (Ahn et al., 2010; Sharma \& Iselin, 2012). In particular, Ahn et al. (2010) found that companies that were acquired with boards where the majority of outside directors served on other board seats experienced negative abnormal returns.

In this regard, Ferris et al. (2003) found that the initial appointment of directors with multiple directorships was well accepted by shareholders, who expected that such directors would benefit the firm in terms of improving the quality of financial reporting.

In addition, directors with multiple directorships who serve on an AC gain the respect of management and would be in a better position in working with auditors (Sharma \& Iselin, 2012). This suggests that multiple-directorship directors would work evenly with the different interest groups in companies and would be more aligned with the interest of shareholders rather than acting for management at the expense of shareholders.

It is expected, based on the reputation hypothesis, that directors with multiple directorships will be more qualified (Fama \& Jensen, 1983) and provide better monitoring work than those with single and double directorship, which in turn leads their presence to improve the quality of earnings and reduce the level of earnings management.

In sum, this hypothesis predicts a negative relationship between multiple directorship and earnings management. Thus, it is predicted that as the percentage of multiple-directorship members in the AC increases, the quality of the monitoring system increases, leading to a reduction in the level of earnings management.

The alternative hypothesis is the busyness hypothesis. Advocates of this view argue that the more multiple directorships board directors hold, the lower the directors' effectiveness. Directors with multiple directorships have limited time and resources. When they serve on multiple boards, they will be so busy that they will be less effective in fulfilling their monitoring responsibilities for any specific company (Ahn et al., 2010).

Another challenge related to the busyness of directors with multiple directorships is a limitation of having the required information for monitoring decisions. Furthermore, as directors serve on multiple board seats, they will have less time to spend on the AC (Jiraporn et al., 2009), which adversely influences their ability to offer good monitoring.

In this regard, Fich and Shivdasani (2006) found that the companies that had directors with multiple directorships had weaker corporate governance. In addition, the empirical results of Beasley (1996) revealed that as the number of directors with multiple directorships decreased, the likelihood of fraudulent financial reporting decreased. These results imply that directors who serve on multiple boards are so busy that they cannot contribute to the effectiveness of the monitoring system. 
Similarly, Sharma and Iselin (2012) reported a positive association between AC multiple directorship and financial misstatements, suggesting that AC members who serve on multiple boards may not offer better monitoring.

It is expected, consistent with the busyness hypotheses, that ACs with multiple directorships are unable to carry out their monitoring functions effectively. In other words, directors who serve on multiple boards spend less time on AC monitoring functions, which affects their effectiveness in monitoring financial reporting and ultimately leads to a higher level of earnings management.

Overall, because studies reported in the literature have provided inconsistent findings on this issue, the current study did not suggest any direction with respect to the association between the multiple directorship of AC members and earnings management. Thus, the first hypothesis of the current study is developed in alternative form, as follows:

H1: There is association between the percentage of AC members with multiple directorships and earnings management.

\subsection{AC Stock Ownership and Earnings Management}

In general, studies have focused on the alignment hypothesis to predict the association between stock ownership and earnings management. The alignment hypothesis contends that companies use stock ownership to encourage their directors to be more committed and aligned with the interest of shareholders (Jensen \& Meckling, 1976). (Note 3)

The advocates of this view argue that when directors hold a stock interest in their companies, they become, by default, shareholders; thus, they will be more motivated to achieve the goals of shareholders (Ahn et al., 2010; Jiraporn et al., 2009) and have less incentive to engage in aggressive reporting.

In this regard, Teshima and Shuto (2008) theorized that directors, who hold stock in their companies, perform to a higher level, including in activities related to the financial reporting process. Meanwhile, Jensen (1993) argued that the more equity outside directors hold in their companies, the more effective they are in monitoring top management.

Consistent with this view, Beasley (1996) found that as the level of ownership of a firm's stock held by outside directors increased, the likelihood of fraudulent reporting decreased. Likewise, the results of Shivdasani (1993) provided evidence that the higher the level of outside directorial ownership, the greater the quality of monitoring.

Thus, it is proposed that the higher the level of ownership of the firm's stock held by directors, the greater the monitoring quality, leading to lower incentives to manage earnings. Hence, to examine the association between the levels of stock ownership held by AC members and earnings management, the second hypothesis of this study is stated, in alternative form, as follows:

$\mathrm{H} 2$ : There is negative association between the percentage of AC members holding common stock shares and earnings management.

\section{Method}

\subsection{Sample Selection}

The initial sample is drawn from the Saudi Stock Exchange (TADAWL), consisting of all Saudi nonfinancial listed companies in 2013. The current study focuses on one fiscal year (2013) because data is not available from the TADAWL as much as needed. The difficulties in collecting data from the official site of TADAWL resulted in small sample size. Nonetheless, the sample represents more than two-thirds of Saudi non-financial listed companies in 2013.

Banks and insurance companies are excluded from the sample due to their unique regularity system. In addition, the financial statements of such companies are not under the regulations of CMA, while they are in concurrence with the regulations of the Saudi Arabian Monitory Agency (SAMA). Notably, these specific regulations would result in differences in incentives and opportunities to exercise earnings management.

The criterion for using the modified Jones model specified by DeFond and Jiambalvo (1994), i.e., a minimum of six cases in each industry, is met by the sample. On the other hand, the sample excludes outliers and cases with incomplete data. Overall, these criteria yield a final sample of 98 Saudi nonfinancial listed companies, as shown in Table 1. 
Table 1. Sample Size

\begin{tabular}{ll}
\hline Initial sample & 114 \\
\hline Less: companies with incomplete financial data & 3 \\
Less: companies cannot be attributed to specific sector & 5 \\
Less: outliers & 8 \\
Total companies removed & 16 \\
Final sample & 98 \\
\hline
\end{tabular}

For the purpose of applying the modified Jones model, both TADAWL and the Global Industry Classification Standard (GICS) are used to classify the sample into certain industries. This yields eight industries, each of which contains at least six observations. Although the sample size is relatively small, which might limit the generalization of the results, it represents more than two thirds (86\%) of Saudi nonfinancial listed companies in 2013.

\subsection{Model and Variables}

Consistent with prior research, the current study estimates the following regression model:

AbnAccrual $=\beta 0+\beta 1 \mathrm{ACMULTID}+\beta 2 \mathrm{ACOWNR}+\beta 3 \mathrm{LEV}+\beta 4 \mathrm{LOSS}+\beta 5 \mathrm{SIZE}+\beta 6 \mathrm{LEV}+$ $\beta 7 \mathrm{~B}-\mathrm{EFCTV}+\beta 8 \mathrm{AC}-\mathrm{EFCTV}+\mathrm{e}$

where AbnAccrual is the absolute value of discretionary accruals estimated by the modified Jones (1991) cross-sectional model (Bartov, Gul, \& Tsui, 2000; DeFond \& Jiambalvo, 1994).

Other variables in the model are measured as follows:

\begin{tabular}{|c|c|c|}
\hline ACMULTID & $=$ & The percentage of AC members who hold three or more directorships \\
\hline ACOWNR & $=$ & $\begin{array}{l}\text { The cumulative percentage of common stock shares of the company held by AC } \\
\text { members }\end{array}$ \\
\hline SIZE & $=$ & The natural log of beginning year's assets \\
\hline LEV & $=$ & The ratio of total liabilities to total assets \\
\hline LOSS & $=$ & $\begin{array}{l}\text { Dichotomous variable taking } 1 \text { if the firm reported a net income below } 0 \text { in } 2013 \\
\text { and } 0 \text { otherwise }\end{array}$ \\
\hline B-EFCTV & $=$ & $\begin{array}{l}\text { A composite index of factors representing the effectiveness of the board. One point } \\
\text { is added to the B-EFCTV each time one of the following three factors is higher than } \\
\text { the sample median: (1) board size: the number of board members, (2) board } \\
\text { independence: the percentage of independent board members, and (3) board } \\
\text { meeting: the number of board meetings held }\end{array}$ \\
\hline AC-EFCTV & $=$ & $\begin{array}{l}\text { A composite index of factors representing the effectiveness of the AC. One point is } \\
\text { added to the AC-EFCTV each time one of the following three factors is higher than } \\
\text { the sample median: (1) AC size: the number of AC members, (2) AC } \\
\text { independence: the percentage of independent AC members, and (3) AC meeting: } \\
\text { the number of AC meetings held. }\end{array}$ \\
\hline
\end{tabular}

ACMULTID is the multiple directorships held by outside directors serving on the AC. All directors who are not currently employed by the company are categorized as outside directors. This definition is in concurrence with the definition of the CMA (2006). In addition, this definition allows researchers to capture the effect of the monitoring role of AC directors with multiple directorship (Ahn et al., 2010; Ferris et al., 2003). Consistent with the study of Ferris et al. (2003), this variable is measured by the percentage of AC members who hold three or more directorships. (Note 4)

ACOWNR is the stock ownership held directly or indirectly by AC members. Consistent with prior studies (Beasley, 1996; Lin et al., 2006), this variable is measured by the cumulative percentage of common stock shares of the company held by AC members. (Note 5)

\section{Control Variables}

Consistent with prior studies (Beasley, 1996; Klein, 2002; Lin et al., 2006), our model includes the following variables:

First, LEVERAGE (LEV): This variable is measured by the ratio of total liabilities to total assets; it is expected to find a positive relationship between leverage and earnings management. Second, LOSS (LOSS): this variable is measured using a dichotomous variable taking 1 if the firm reported a net income below 0 in 2013 and 0 
otherwise. The expected sign for loss is positive, implying that when loss increases, earnings management also increases. Third, SIZE (SIZE): this variable is measured by the natural log of the beginning year's assets. It is expected that earnings management is negatively associated with the size of companies, implying that the larger the company, the lower the extent of earnings management. Using one composite index for both the board and AC effectiveness as in Huang, Wang, and Zhou (2013) could be a noisy measure of effectiveness. Instead, in this study, each variable is measured separately. In particular, B-EFCTV is used to capture the effect of board effectiveness on earnings management, while AC-EFCTV is used to control for the effect of AC effectiveness on earnings management. Specifically, the variable B-EFCTV is a single composite index for board effectiveness that includes board independence, meeting, and size, as adopted in prior studies (Klein, 2002; Xie, Davidson, \& DaDalt, 2003). On the other hand, the variable of AC-EFCTV is a single composite index for AC effectiveness that includes AC independence, meeting, and size, as adopted in prior studies (Abbott et al., 2004; Bédard et al., 2004; Klein, 2002).

\section{Results and Discussion}

\subsection{Descriptive Statistics \& Regression Results}

Table 2 summarizes the descriptive statistics of the sample. The mean (median) of abnormal accrual is .049 (.04); the mean (median) stock ownership of AC members is .06 (.005); and the mean (median) multiple directorships per AC member is $.12(0)$. These results indicate that the percentage of AC members holding multiple directorships in Saudi companies is very low, approaching zero.

Table 2. Descriptive Statistics

\begin{tabular}{rrcccc}
\hline Variable & Minimum & Maximum & Mean & Median & Standard deviation \\
\hline AbsAccrual & 0 & 0.13 & 0.049 & 0.04 & 0.037 \\
ACMULTID & 0 & 0.75 & 0.12 & 0 & 0.18 \\
ACOWNR & 0 & 1.45 & 0.06 & 0.005 & 0.17 \\
SIZE & 5.14 & 8.53 & 6.4 & 6.32 & 0.66 \\
LEV & 0.01 & 0.8 & 0.36 & 0.36 & 0.21 \\
LOSS & 0 & 1 & 0.14 & 0 & 0.35 \\
B-EFCTV & 0 & 3 & 1.8 & 2 & 0.71 \\
AC-EFCTV & 0 & 3 & 1.78 & 2 & 0.68 \\
\hline
\end{tabular}

Note. See model specification in section 3 for definitions of variables.

The results reveal that the independent variables are not strongly correlated to each other, with none of the correlation coefficients exceeding .4 (Table 3). The results of the standard regression diagnostics are within acceptable limits (Table 4). The variance inflation factor (VIF) scores are all below ten, implying that the problem of multicollinearity is not significant (Hair, Anderson, Black, Babin, \&Tatham, 2006). Eight cases are excluded after the initial testing for outliers. However, the application of the Mahalanobis distance values test, the final test used to test for outliers, reveals no further multivariate outliers among cases because the Mahalanobis values are less than the critical chi-square of 24.32 for the model at an alpha level of .001 . The overall model is significant ( $\mathrm{p}=.020$ ), with an adjusted $\mathrm{R}^{2}$ of .099 .

Table 3. Pearson Correlation Coefficients

\begin{tabular}{lcccccccc}
\hline & $(1)$ & $(2)$ & $(3)$ & $(4)$ & $(5)$ & \multicolumn{1}{c}{$(6)$} & \multicolumn{1}{c}{$(7)$} & $(8)$ \\
\hline AbsAccrual(1) & 1 & $0.11-$ & $-.17^{*}$ & $-.27^{*}$ & 0.06 & 0.08 & 0.05 & -0.02 \\
ACMULTID(2) & & 1 & -0.1 & 0.1 & 0.04 & -0.11 & 0.17 & -0.01 \\
ACOWNR(3) & & 1 & -0.12 & -0.17 & -0.14 & -0.11 & -0.1 \\
SIZE(4) & & & 1 & $.41^{*}$ & -0.09 & 0.13 & 0.04 \\
LEV(5) & & & & 1 & 0.14 & -0.12 & -0.05 \\
LOSS(6) & & & & & 1 & 0.09 & 0.13 \\
B-EFCTV(7) & & & & & & 1 & $.18^{*}$ \\
AC-EFCTV(8) & & & & & & & 1 \\
\hline
\end{tabular}

Note. Variables are as defined in model specification in section 3. 
Table 4. Regression Result

\begin{tabular}{|c|c|c|c|c|c|}
\hline \multicolumn{6}{|c|}{ AbnAccrual $=\beta 0+\beta 1$ ACMULTID $+\beta 2$ ACOWNR $+\beta 3$ LEV $+\beta 4$ LOSS $+\beta 5$ SIZE $+\beta 6+\beta 7$ B-EFCTV $+\beta 8$ AC-EFCTV $+\mathrm{e}$} \\
\hline Variables & Exp sign & $\beta$ & VIF & t-value & p-value* \\
\hline Intercept & \multicolumn{3}{|c|}{0.16} & 4.2 & 0 \\
\hline \multicolumn{6}{|l|}{ Control } \\
\hline SIZE & - & -0.02 & 1.31 & -3.45 & 0.001 \\
\hline LEV & + & 0.04 & 1.34 & 1.8 & 0.075 \\
\hline LOSS & + & -0.003 & 1.12 & -0.26 & 0.794 \\
\hline B-EFCTV & - & 0.01 & 1.14 & 1.29 & 0.2 \\
\hline AC-EFCTV & - & -0.002 & 1.06 & -0.31 & 0.76 \\
\hline \multicolumn{6}{|l|}{ Experimental } \\
\hline ACMULTID & $-/+$ & -0.026 & 1.06 & -1.23 & 0.22 \\
\hline ACOWNR & - & -0.005 & 1.08 & -1.91 & 0.059 \\
\hline
\end{tabular}

$R^{2}=.16$, Adjusted $R^{2}=0.099, F$-ratio $=2.526$, Signif. $F<0.05, \mathrm{n}=98$

Note. *p-values represent one-tailed tests when direction of coefficient is consistent with expectations; variables are as defined in model specification in section 3.

The regression results show that the multiple directorship of AC members is not significant $(\mathrm{p}=.221)$, implying that holding multiple directorships is not associated with a reduction in AC members' level of earnings management. Hence, the first hypothesis of this study is not supported. A possible reason for this result is that there is a shortage of multiple-directorship directors serving on ACs in Saudi companies. On average, the percentage of AC members holding multiple directorships in Saudi companies is very low, approaching zero (.12). The descriptive information also shows that approximately 41 percent of directors serving on ACs hold single or double directorship, a further indication of the shortage of AC members holding multiple directorships (three or more directorships) in Saudi companies. The result also implies that having AC members with multiple directorships receives low priority from the board. However, it also implies that Saudi companies tend to not adhere to the formal governance regulation issued by CMA, which encourages directors to be members of other boards of directors (CMA, 2006). While that is implicitly mentioned in the corporate governance regulation, it is recommended that directors not be a member of more than five joint stock companies simultaneously (CMA, 2006). This regulation indicates that CMA does consider the role of multiple directorship in improving the monitoring system.

Overall, these results are consistent with those documented in Ferris et al. (2003), who found no relationship between directorship and the likelihood of securities fraud litigation. However, the current study is not in concurrence with the results reported in other prior studies (Beasley, 1996; Sharma \& Iselin, 2012). The differences may reflect the lack of importance attached to having AC directors with multiple directorships in Saudi listed companies compared to companies in advanced countries.

Regarding AC stock ownership, the results reveal that the stock ownership of AC members is significantly negatively associated with the level of earnings management, at the ten percent alpha level (marginally significant at the five percent alpha level; $\mathrm{p}=.059$ ). This result implies that when the cumulative percentage of the stock interest of the company held by AC members increases, the level of earnings management decreases. Hence, the second hypothesis of this study is supported. (Note 6)

This result is in support of the alignment hypothesis, which proposes that outside directors will be more aligned with the interests of shareholders if they hold a stock interest in the company. As a consequence, the monitoring role of outside directors will increase, and the level of the earnings management will decrease. The result is also consistent with those of Beasley (1996), who found that as the stock ownership of outside members increased, the likelihood of financial statement fraud decreased.

In terms of control variables, company size (SIZE) is statistically significant at the five percent alpha level ( $\mathrm{p}=.001$ ), while leverage is significant at the ten percent alpha level $(\mathrm{p}=.075)$. The coefficient of size (SIZE) is negative, as predicted, implying that the larger the company, the lower the extent of earnings management. Likewise, the coefficient of leverage (LEV) is consistent with the expectation, as the result shows a positive effect of leverage on the incentive to exercise earnings management in Saudi nonfinancial listed companies.

However, contrary to expectations, this study finds that AC effectiveness, as measured by the composite index of factors including the size, independence, and frequency of meetings of the AC, is not significant ( $p=.76)$. Similarly, the results show that board effectiveness is not an important factor in reducing the level of earnings management, as measured by the composite index of factors including the size, independence, and frequency of meetings of the board $(p=.20)$. Finally, the results reveal that there is no relationship between the company's loss and the level of earnings management $(\mathrm{p}=.794)$. 


\subsection{Supplementary Analysis}

This analysis addresses three issues: the alternative measurement of variables, the relation specification, and the endogeneity test.

\subsubsection{The Alternative Measurement of Variables}

Prior studies have used several measurements to measure multiple directorship, including the total number of other directorships held by independent directors divided by the number of outside directors (Ahn et al., 2010); the maximum number of multiple directorships held by AC members (Ferris et al., 2003); a dummy variable taking one if at least one AC member serves on three or more other board seats and zero otherwise (Sharma \& Iselin, 2012); and the average number of multiple directorships held by outside directors (Ferris et al., 2003). The results (not reported) reveal that none of the above measurements is significant ( $p=.949 ; \mathrm{p}=.622 ; \mathrm{p}=.369 ; \mathrm{p}=.240$, respectively), suggesting that the multiple directorship of AC members has no significant impact on earnings management.

In addition, the number of multiple directorships based on Saudi regulator criteria, which limit multiple directorship to holding 5 other board seats, is used to measure multiple directorship. The results reveal that the multiple directorship of AC members is not significant ( $\mathrm{p}=.497)$, implying that this criterion is not important to improve the monitoring role of directors with multiple directorships. This result suggests that Saudi regulators should review the current regulation on holding multiple directorships. While it is an unparalleled regulation compared to those applied in advanced countries, it has no impact on FRQ. (Note 7)

\subsubsection{Relation Specification}

The aim of this test is to examine whether the relations between the variables differ based on the variation in the level of independent variables. In this context, Ahn et al. (2010) found that the impact of multiple directorship was constant across the entire range of multiple directorship.

The range measure is used to divide the sample into five thresholds based on the median value. This requirement yields five models to test the proposition that the impact of the multiple directorship of AC members might change across the entire range of the multiple directorship of AC members.

In model 1, ACMULTID is replaced by the variable defined as a dummy variable taking one if the percentage of $\mathrm{AC}$ members who hold three or more directorships is above the median value and zero otherwise. Based on information in Table 5, the results reveal that the multiple directorship of AC members is not significant ( $\mathrm{p}=.32)$. In models 2 and 3, the sample is divided based on two threshold levels representing the interquartile range (i.e., the scores between the first quartile and the third quartile) and the top quartile. The results show that the association between the multiple directorship of $\mathrm{AC}$ members and the level of earnings management does not differ across the different levels of AC multiple directorship ( $\mathrm{p}=.97 ; \mathrm{p}=.87$ ). In models 4 and 5 , two other threshold points are identified representing the scores between the median to the third quartile and the scores below the median value. The results indicate that the multiple directorship of AC members is not significantly associated with a reduction in earnings management $(\mathrm{p}=.51 ; \mathrm{p}=.32$, respectively). Overall, the results of the supplementary analysis confirm that the multiple directorship of AC members is not significantly associated with a reduction in the level of earnings management. In other words, the association between the multiple directorship of $\mathrm{AC}$ members and earnings management is constant for the low, intermediate, and high levels of the multiple directorship of AC members.

Table 5. Supplementary Analysis: Multiple Regression of Earnings Management on AC Multiple-Directorships (model 1-5)

\begin{tabular}{rcccccc}
\hline Variables & Exp sign & Model 1 & Model 2 & Model 3 & Model 4 & Model 5 \\
\hline Control & & & & & & \\
SIZE & - & $.00^{*}$ & $.00^{* *}$ & $.00^{*}$ & $.00^{*}$ & $.00^{*}$ \\
LEV & + & .11 & $.09^{* *}$ & .10 & .10 & .11 \\
LOSS & + & .95 & .92 & .94 & .93 & .95 \\
B-EFCTV & - & .37 & .28 & .32 & .31 & .37 \\
AC-EFCTV & - & .91 & .80 & .72 & .85 & .90 \\
Experimental & & & & & & \\
ACMULTID & $-/+$ & .32 & .97 & .87 & .51 & .32 \\
ACOWNR & - & $.08^{* *}$ & $.08^{* *}$ & $.06^{* *}$ & $.08^{* *}$ & $.08^{* *}$ \\
\hline
\end{tabular}

Note. $*, * *$ Represent statistical significant at $\mathrm{P}<.05, \mathrm{P}<.10$, respectively. One-tailed test for a directional predicted sign, and two-tailed otherwise. 
With regard to stock ownership by AC members, the current study also examines whether the relation between the stock ownership of AC members and earnings management differ based on the level of stock ownership of AC members. In this context, Warfield et al., (1995) found that an inverse relation between the stock ownership held by directors and the level of earnings management was constant for different levels of stock ownership.

To test whether the relations change based on AC members' level of stock ownership, the median value is used to identify four threshold points. Hence, the current study develops four models with four variables representing different levels of AC ownership: the scores below the median value (ACOWNR1); the scores between the median value (i.e., the second quartile) and the third quartile (ACOWNR2); the scores above the median value (ACOWNR3); and the scores above the third quartile (ACOWNR4).

The results (not reported) show that the coefficients of three first variables (ACOWNR1, 2, and 3) are not significant ( $\mathrm{p}=.22, \mathrm{p}=.23, \mathrm{p}=226$, respectively). However, the coefficient of the fourth variable (ACOWNR4) is significant with the expected sign $(\mathrm{p}=.004)$, suggesting that as the stock ownership of AC members increases, the level of earnings management decreases only in situations where there is a high level of AC ownership.

\subsubsection{Endogeneity Test}

It has been reported in the literature that the presence of multiple directorship is determined exogenously by external factors that might affect study results (Booth \& Deli, 1996; Brickley, Linck \& Coles, 1999; Ferris et al., 2003). (Note 8)

Conversely, it is suggested that while AC members' multiple directorship influences the level of earnings management, the presence of multiple directorship itself might also be influenced by the level of earnings management. In this regard, Srinivasan (2005) found that misstated companies that had directors with multiple directorships suffered from labor market penalties; in particular, such directors lost their positions on ACs following a restatement.

To alleviate this concern, the current study uses a simultaneous equation approach as in (Coles, Daniel, \& Naveen, 2008). This approach is based on using a two-stage least squares (2SLS) regression. Several variables are included in the 2SLS model to determine the variability in endogenous variables, including board independence (B-IND), board size (B-SIZE), company size (SIZE), return on assets (ROA), and earnings management, as measured by abnormal accrual (AbnAccrual).

The results, as reported in Table 6, show that the multiple directorship of AC members is not influenced by the level of earnings management $(\mathrm{p}=.944)$. On the other hand, the results show that stock ownership of AC members is significantly negatively associated with the reduction in the level of earnings management $(\mathrm{p}=.066)$. Overall, the results indicate that endogeneity is not a critical issue in the relation between the multiple directorship of AC members and companies' earnings management.

Table 6. Endogeneity Results

\begin{tabular}{lcc}
\hline Independent variables & AbnAccrual & AC multiple-directorships \\
\hline B-EFCTV & .258 & \\
AC-EFCTV & .959 & \\
ACMULTID & .463 & \\
ACOWNR & $.066^{*}$ & \\
LEV & .165 & .292 \\
SIZE & $.017 * *$ & .944 \\
AbnAccrual & & .147 \\
ROA & & \\
LOSS & .702 & .489 \\
B-IND & & $.025^{* *}$ \\
B-SIZE & & \\
\hline
\end{tabular}

Note. $*(* *)$ Significant at the $.10(.05)$ level.

\section{Conclusion}

The aim of this study is to examine the association between the multiple directorship and stock ownership of AC members and companies' earnings management.

With regard to the multiple directorship of AC members, prior studies are based on two competing hypotheses. Under the reputation hypothesis, it is proposed that directors with multiple directorships offer better monitoring work than do directors with single and double directorships. It is assumed that they will be more effective in fulfilling their monitoring role and thus contribute more to earnings quality in terms of reducing the level of earnings management. On the other hand, the busyness hypothesis contends that as the number of multiple 
directorships held by directors increases, they become so busy that they are unable to fulfill the requirements of their monitoring role. This, in turn, will adversely affect their effectiveness in reducing the level of earnings management.

Contrary to expectations, the current study finds that the multiple directorship of AC members is not statistically associated with any reduction in the level of earnings management. This might be due to the shortage of multiple-directorship directors serving on ACs of Saudi companies. The descriptive information shows that approximately 41 percent of directors serving on ACs have single or double directorships. This result implies that management gives low priority to ensuring that $\mathrm{AC}$ members hold multiple directorships. Furthermore, it suggests that Saudi companies tend to not to adhere to the provisions of the formal governance act issued by CMA, which encourages directors to hold memberships on other boards of directors.

In terms of stock ownership by AC members, the alignment hypothesis contends that when members of a board hold quantities of stock, they are more committed in their work, which leads them to perform better in monitoring activities. It is proposed, based on this argument, that the greater the percentage of stock ownership held by AC members, the higher the quality of the monitoring system, leading to a reduction in the level of earnings management.

The results of the study provide evidence supporting the alignment hypothesis, suggesting that the size of the stock ownership of AC members has a significant impact on earnings management in Saudi nonfinancial listed companies.

A supplementary test provides additional evidence for the positive impact of stock ownership by AC members on the level of earnings management. Interestingly, the finding shows this relationship is significant only when the level of stock ownership by AC members is high; it is not significant for intermediate and low levels of AC stock ownership.

This study is among the few studies that seek to provide evidence on the association between multiple directorship and the stock ownership of AC members with companies' earnings management. It sheds light on the current debate concerning the impact of both the multiple directorship and stock ownership of AC members on earnings management. While most previous studies have been conducted in advanced countries, this study presents evidence from an emerging economy, i.e., Saudi Arabia.

The findings of the study are useful for directors of Saudi companies to initiate long-term plans to overcome the shortage of multiple-directorship directors serving on ACs and to develop strategies to increase the stock ownership of $\mathrm{AC}$ members as a means of achieving better monitoring outcomes.

The findings can also provide regulators (i.e., CMA) with a better understanding of the current situation of the multiple directorship and stock ownership of AC members in Saudi companies. This may help improve the regulations related to $\mathrm{ACs}$ as a corporate governance mechanism and, specifically, regulations related to the multiple directorship and stock ownership of AC members.

A concern that might be raised regarding the result of this study is the sample size. In fact, because the difficulties in collecting data from TADAWL, the current study focuses on one fiscal year (2013). Although the sample size represents more than two-thirds of Saudi non-financial listed companies in 2013, it might be relatively small, which might limit the generalization of this study. Researchers should concern this issue and increase the sample size to include more than one fiscal year as data become more available in the future.

To conclude, the following opportunities are suggested for future research in this area: an investigation into the effect of various factors that might influence the effectiveness of multiple directorship, the stock ownership of $\mathrm{AC}$ members and their impact on earnings management. The impact of the multiple directorship and stock ownership of AC members on the value of a firm might also be explored in future research, specifically in an emerging economy such as that of Saudi Arabia.

\section{References}

Abbott, L. J., Park, Y., \& Parker, S. (2000). The effects of audit committee activity and Independence on corporate fraud. Managerial Finance, 26, 55-68. http://dx.doi.org/10.1108/03074350010766990

Abbott, L. J., Parker, S., \& Peters, G. F. (2004). Audit committee characteristics and restatements. Auditing: A Journal of Practice \& Theory, 23, 69-87. http://dx.doi.org/10.2308/aud.2004.23.1.69

Ahn, S., Jiraporn, P., \& Kim, Y. S. (2010). Multiple directorships and acquirer returns. Journal of Banking \& Finance, 34, 2011-2026. http://dx.doi.org/10.1016/j.jbankfin.2010.01.009

Alves, S. (2012). Ownership structure and earnings management: Evidence from Portugal. Australasian 
Accounting Business \& Finance Journal, 6, 57-73.

Bartov, E., Gul, F. A., \& Tsui, J. S. L. (2000). Discretionary-accruals models and audit qualifications. Journal of Accounting and Economics, 30, 421-452. http://dx.doi.org/10.1016/S0165-4101(01)00015-5

Beasley, M. S. (1996). An empirical analysis of the relation between the board of director composition and financial statement fraud. Accounting Review, 71, 443-465.

Bédard, J., Chtourou, S. M., \& Courteau, L. (2004). The effect of audit committee expertise, independence, and activity on aggressive earnings management. Auditing: A Journal of Practice \& Theory, 23, 13-35. http://dx.doi.org/10.2308/aud.2004.23.2.13

Beneish, M. D. (2001). Earnings management: A perspective. Managerial Finance, 27, 3-17. http://dx.doi.org/10.1108/03074350110767411

Booth, J. R., \& Deli, D. N. (1996). Factors affecting the number of outside directorships held by CEOs. Journal of Financial Economics, 40, 81-104. http://dx.doi.org/10.1016/0304-405X(95)00838-6

Brickley, J., Linck, J. S., \& Coles, L. (1999). What happens to CEOs after they retire? New evidence on career concerns, horizon problems, and CEO incentives. Journal of Financial Economics, 52, 341-377. http://dx.doi.org/10.1016/S0304-405X(99)00012-4

Capital Market Authority. (2006). Corporate governance regulation. Retrived from http://www.cma.org.sa/En/Documents/CORPORATE\%20GOVERNANCE.pdf

Coles, J., Daniel, N., \& Naveen, L. (2008). Boards: Does one size fit all? Journal of Financial Economics, 87, 329-356. http://dx.doi.org/10.1016/j.jfineco.2006.08.008

DeFond, M. L., \& Jiambalvo, J. (1994). Debt covenant violation and manipulation of accruals. Journal of Accounting and Economics, 17, 145-176. http://dx.doi.org/10.1016/0165-4101(94)90008-6

Fama, E. F., \& Jensen, M. C. (1983). Separation of ownership and control. The Journal of Law and Economics, 26, 301-325. http://dx.doi.org/10.1086/467037

Farber, D. B. (2005). Restoring trust after fraud: Does corporate governance matter? The Accounting Review, 80, 539-561. http://dx.doi.org/10.2308/accr.2005.80.2.539

Ferris, S. P., Jagannathan, M., \& Pritchard, A. C. (2003). Too busy to mind the business? Monitoring by directors with multiple board appointments. The Journal of Finance, 58, 1087-1111. http://dx.doi.org/10.1111/1540-6261.00559

Fich, E. M., \& Shivdasani, A. (2006). Are busy boards effective monitors? The Journal of Finance, 61, 689-724. http://dx.doi.org/10.1111/j.1540-6261.2006.00852.x

Hair, J. F., Anderson, R. E., Babin, B. J., Black, W. C., \& Tatham, R. L. (2006). Multivariate Data Analysis. London: Prentice-Hall International.

Huang, H. H., Wang, W., \& Zhou, J. (2013). Shareholder rights, insider ownership and earnings management. Journal of Accounting, Finance and Business Studies, 49, 46-73. http://dx.doi.org/10.1111/j.1467-6281.2012.00390.x

Jensen, M. C. (1993). The modern industrial revolution, exit, and the failure of internal control systems. The Journal of Financial, 48, 831-880. http://dx.doi.org/10.1111/j.1540-6261.1993.tb04022.x

Jensen, M. C., \& Meckling, W. H. (1976). Theory of the firm: Managerial behavior, agency costs and ownership structure. Journal of Financial Economics, 3, 305-360. http://dx.doi.org/10.1016/0304-405X(76)90026-X

Jiraporn, P., Singh, M., \& Lee, C. I. (2009). Ineffective corporate governance: Director busyness and board committee memberships. Journal of Banking \& Finance, 33, 819-828. http://dx.doi.org/10.1016/j.jbankfin.2008.09.020

Jones, J. (1991). Earnings management during import relief investigations. Journal of Accounting Research, 29 (2), 193-228. http://dx.doi.org/10.2307/2491047

Klein, A. (2002). Audit committee, board of director characteristics, and earnings management. Journal of Accounting and Economics, 33, 375-400. http://dx.doi.org/10.1016/S0165-4101(02)00059-9

Krishnan, J., Wen, Y., \& Zhao, W. (2011). Legal expertise on corporate audit committees and financial reporting quality. The Accounting Review, 86, 2099-2130. http://dx.doi.org/10.2308/accr-10135

Lin, J. W., Li, J. F., \& Yang, J. S. (2006). The effect of audit committee performance on earnings quality. 
Managerial Auditing Journal, 21, 921-933. http://dx.doi.org/10.1108/02686900610705019

Perry, T. O. D., \& Peyer, U. R. S. (2005). Board seat accumulation by executives: A shareholder's perspective. The Journal of Finance, 60, 2083-2123. http://dx.doi.org/10.1111/j.1540-6261.2005.00788.x

Schipper, K. (1989). Earnings management. Accounting Horizons, 3(4), 91-102.

Sharma, V. D., \& Iselin, E. R. (2012). The association between audit committee multiple-directorships, tenure, and financial misstatements. Auditing: A Journal of Practice \& Theory, 31, 149-175. http://dx.doi.org/10.2308/ajpt-10290

Shivdasani, A. (1993). Board composition, ownership structure, and hostile takeovers. Journal of Accounting and Economics, 16, 167-198. http://dx.doi.org/10.1016/0165-4101(93)90009-5

Srinivasan, S. (2005). Consequences of financial reporting failure for outside directors: Evidence from accounting restatements and audit committee members. Journal of Accounting Research, 43, 291-334. http://dx.doi.org/10.1111/j.1475-679x.2005.00172.x

Teshima, N., \& Shuto, A. (2008). Managerial ownership and earnings management: Theory and empirical evidence from Japan. Journal of International Financial Management \& Accounting, 19, 107-132. http://dx.doi.org/10.1111/j.1467-646X.2008.01018.x

Velte, P., \& Stiglbauer, M. (2011). Impact of audit committees with independent financial experts on accounting quality. An empirical analysis of the German capital market. Problems and Perspectives in Management, 9, 17-33.

Warfield, T. D., Wild, J. J., \& Wild, K. L. (1995). Managerial ownership, accounting choices, and informativeness of earnings. Journal of Accounting and Economics, 20, 61-91. http://dx.doi.org/10.1016/0165-4101(94)00393-J

Xie, B., Davidson, W. N., \& DaDalt, P. J. (2003). Earnings management and corporate governance: The role of the board and the audit committee. Journal of Corporate Finance, 9, 295-316. http://dx.doi.org/10.1016/S0929-1199(02)00006-8

\section{Notes}

Note 1. Contrasting to the alignment hypothesis, the entrenchment hypothesis proposes that as ownership increases, directors with a higher percentage of ownership might control the companies in a manner that limits the role of the monitoring system, including the AC. Such a situation could lead to an increased incentive to manage earnings.

Note 2. As cited in Beneish, 2001.

Note 3. Considering that the CMA requires each company to set up an AC with not less than three members and that only outside members are eligible for membership of the AC, the association between managerial ownership and earnings management is beyond the scope of this study.

Note 4. Outside directors can be either grey directors or independent directors (Beasley, 1996). Based on this categorization, the grey directors include all outside directors who are not viewed as being independent from management, such as consultants/ suppliers to the company or investment bankers; while the independent directors include all outside directors excluding grey directors; since outside directors(including both grey and independent directors) are only eligible for membership of the AC according to CG regulation in Saudi Arabia, the measure of AC multiple-directorships in this study is based on multiple-directorships of the outside directors who serve on AC.

Note 5. To fulfill the assumption of normality, the log of ACOWNR is used. After making transformations for this variable, the value of skewness and kurtosis reveal that all variables in the model fulfill the assumption of normality.

Note 6. The result is the same when AC multi-directorship and Ac ownership are isolated from the analysis.

Note 7. Since most prior studies in the area of stock ownership are interested in the impact of managerial ownership on the quality of earnings (Alves, 2012; Huang et al., 2013; Warfield et al., 1995), the alternative measurement of stock ownership is beyond the scope of this study.

Note 8. None of the literature reported an endogeneity problem with the relation between AC outside ownership and earnings management. 


\section{Appendix}

\section{Abnormal Accrual}

Abnormal Accrual (AbnAccrual) is defined as follows:

NDAC ijt $\quad=$

$$
\alpha_{\mathrm{j}}[1 / \mathrm{Aijt}-1]+\beta 1 \mathrm{j}\left[\Delta \mathrm{REV}_{\mathrm{ijt}}-\Delta \mathrm{REC}_{\mathrm{ijt}} / \mathrm{A}_{\mathrm{ijt}}-1\right]+\beta 2 \mathrm{j}\left[\mathrm{PPE}_{\mathrm{ijt}} / \mathrm{A}_{\mathrm{ijt}}-1\right]
$$

$$
\text { AbnAccrual }_{\mathrm{ijt}}=\mathrm{TAC}_{\mathrm{ijt}}-\mathrm{NDAC}_{\mathrm{ijt}}
$$

where

$$
\begin{aligned}
\triangle \mathrm{REV} \text { ijt } & =\text { the change in revenue for firm } \mathrm{i} \text { in industry } \mathrm{j} \text { between year } \mathrm{t}-1 \text { and } \mathrm{t} \\
\mathrm{PPE} \text { ijt } & =\text { gross property, plant and equipment for firm } \mathrm{i} \text { in year } \mathrm{t} \\
\mathrm{A} \mathrm{ijt}-1 & =\text { total assets for firm } \mathrm{i} \text { in industry } \mathrm{j} \text { at the end of the previous year } \\
\triangle \mathrm{REC} \text { ijt } & =\text { the change in receivables for firm } \mathrm{i} \text { in industry } \mathrm{j} \text { between year } \mathrm{t}-1 \text { and } \mathrm{t}
\end{aligned}
$$

where $\alpha \mathrm{j}, \beta 1 \mathrm{j}$ and $\beta 2 \mathrm{j}$ are industry-specific coefficients estimated from the following cross-sectional regression:



\section{Copyrights}

Copyright for this article is retained by the author(s), with first publication rights granted to the journal.

This is an open-access article distributed under the terms and conditions of the Creative Commons Attribution license (http://creativecommons.org/licenses/by/4.0/). 